\title{
PELETAKAN SITA JAMINAN ATAS HAK KEKAYAAN INTELEKTUAL
}

\author{
Ambrosius Adjie \\ email: ambrosiusadjie2@gmail.com
}

\begin{abstract}
This study aims to determine the placement of sequestration of intellectual property rights. This study uses normative research, the research specification descriptive analysis, this research is carried out through the stage of the study of literature, and data analysis conducted qualitative normative. Results of this study show that can be placed sequestration of intellectual property rights, which lies in the economic value of the intellectual property rights.
\end{abstract}

Keywords:

Sequestration, Intellectual property rights, object Intellectual property rights, intangible object.

\begin{abstract}
Abstrak
Kajian ini dilaksanakan untuk menjelaskan peletakan sita jaminan atas hak kekayaan intelektual. Penelitian ini menggunakan metode penelitan yuridis normatif, dengan spesifikasi penelitan deskriptif analisis, penelitan ini dilaksanakan melalui tahap studi kepustakaan, dan analisis data dilakukan secara normatif kualitatif. Hasil kajian ini menunjukkan bahwa dapat diletakan sita jaminan atas hak kekayaan intelektual, yang terletak pada nilai ekonomi dari hak kekayaan intelektual tersebut.
\end{abstract}

Kata Kunci:

Sita jaminan, hak kekayaan intelektual, obyek hak kekayaan intelektual, benda tidak berwujud.

\section{Pendahuluan}

Dewasa ini perkembangan permasalahan hukum di Indonesia sangat pesat dan tidak diimbangi oleh perkembangan hukum positif di Indonesia, sehingga dibutuhkan berbagai macam penafsiran terhadap hukum positif di Indonesia. Dari permasalahan hukum yang begitu banyak di Indonesia, tidak sedikit yang membutuhkan penyelesaian hukum melalui jalur litigasi atau melalui proses peradilan. Namun yang menjadi permasalahan di sini ketika masalah tersebut terjadi di lapangan, kaum praktisi hukum di Indonesia terutama advokat, mengalami kesulitan dalam hal melakukan investigasi mengenai harta dari pihak tergugat yang pada akhirnya akan diletakkan sita jaminan.

Berdasarkan hal tersebut, yang menjadi inti dari diletakkannya sita jaminan adalah apabila tergugat tidak melaksanakan suatu putusan secara 
sukarela, maka sita jaminan tersebut dapat dieksekusi dan dapat dikatakan sebagai suatu bentuk kepastian hukum bagi pihak yang 'menang' dalam suatu sengketa. Tetapi fakta yang terjadi di lapangan adalah tidak sedikit pihak yang menjadi tergugat di dalam sengketa tidak memiliki aset/harta yang memiliki nilai ekonomis yang cukup untuk dijaminkan.

Sebagai gambarannya, apabila dalam kasus gugatan perbuatan melawan hukum, dalam hal ini adalah pihak X, telah dinyatakan melakukan suatu tindak pidana oleh hakim, dan putusan tersebut telah memiliki kekuatan hukum tetap, maka terhadap Pihak $\mathrm{X}$ tersebut dapat diajukan gugatan perbuatan melawan hukum. Hal ini dikarenakan pihak yang dirugikan memiliki upaya hukum untuk meminta ganti rugi secara perdata. Kemudian apabila hakim telah menjatuhkan putusan yang berkekuatan tetap, maka X harus memberikan ganti rugi sejumlah uang kepada si penggugat. Namun yang sering terjadi adalah apabila pada akhirnya $\mathrm{X}$ tidak melaksanakan putusan tersebut secara sukarela, upaya hukum apa yang harus dilakukan oleh si penggugat? Berangkat dari hal tersebut, dirasakan penting sita jaminan di dalam penyelesaian sengketa melalui jalur litigasi demi terwujudnya kepastian hukum bagi pihak yang dirugikan.

Sebagaimana dijabarkan di atas, permasalahan yang muncul adalah sebagai berikut: apakah suatu aset/harta selalu dapat berupa benda berwujud yang lazimnya dijadikan sebagai suatu sita jaminan? Dalam kenyataannya, suatu aset/harta ada pula yang berupa benda tidak berwujud yang memiliki nilai ekonomi misalnya hak kekayaan intelektual. Berdasarkan hal tersebut muncul pertanyaan lanjutan; dan apakah bisa kita mengajukan sita jaminan atas hak kekayaan intelektual?

Secara sederhana, sita jaminan adalah penyitaan yang dilakukan oleh pengadilan atas barang bergerak atau tidak bergerak, milik penggugat atau tergugat untuk menjamin adanya tuntutan hak dari pihak yang berkepentingan atau pemohon sita. Penyitaan ini merupakan tindakan persiapan untuk menjamin dapat dilaksanakannya putusan perdata. Tersirat makna bahwa sita jaminan dilakukan atas hak milik dari seseorang namun terbatas kepada benda bergerak 
dan tidak bergerak, sebagaimana ditegaskan di dalam pasal 1131 KUHPerdata yang merupakan asas umum dari sita jaminan.

Secara sederhana konsep hak kekayaan intelektual adalah memberikan pengakuan terhadap hasil karya individu yang telah menciptakan penemuan atau karya intelektual tertentu yang diakui oleh masyarakat serta hak ekonomi yang menyertai karya tersebut. Melihat konsep hak intelektual secara sederhana tersebut, tersirat makna, bahwa melekat pula hak milik di dalam hasil karya intelektual tersebut, namun hak milik tersebut berupa benda yang tidak berwujud.

Berdasarkan uraian di atas, maka permasalahannya adalah: Apakah dapat diletakkan sita jaminan terhadap obyek hak kekayaan intelektual? Karena di dalam hukum positif di Indonesia, sita jaminan lebih sering diletakkan atas benda yang berwujud.

\section{Pembahasan}

Hukum acara atau sering juga disebut sebagai hukum formil merupakan hukum yang memiliki fungsi menegakkan hukum materiil, substansinya berisi prosedur-prosedur yang harus ditempuh dan dipatuhi oleh aparat penegak hukum dan pihak-pihak yang bersengketa. Hukum acara perdata sendiri mengatur tentang bagaimana caranya mengajukan tuntutan hak, memeriksa serta memutusnya dan pelaksanaan dari putusannya ${ }^{1}$.

Dalam upaya pelaksanaan penegakan hukum seringkali diperlukan tindakan-tindakan paksa yang bersifat mencegah kerugian ataupun pemulihan kerugian yang diderita oleh pihak yang merasa dirugikan. Tindakan paksa dalam hukum acara perdata hanya bisa dilakukan berdasarkan suatu penetapan dari hakim pengadilan yang berwenang. Adapun bentuk-bentuk tindakan paksa itu dapat berupa ${ }^{2}$ :

1) putusan provisional berupa perintah penghentian sementara suatu pekerjaan/ perbuatan tertentu hingga dijatuhkan suatu putusan akhir;

1 Sudikno Mertokusumo, Hukum Acara Perdata Indonesia 2 (Liberty, Yogyakarta, 1998)

2 M. Yahya Harahap, Ruang Lingkup Permasalahan Eksekusi Bidang Perdata 23, (Sinar Grafika, Jakarta, 2006) 
2) penetapan sita baik berupa: sita jaminan (conservatoir beslag), sita matrimonial (dalam perkara perceraian), dan sita revindikasi (dalam sengketa hak milik);

3) putusan sela berupa perintah penitipan barang sengketa kepada pihak ketiga selama berlangsungnya pemeriksaan perkara (sekestrasi); dan

4) putusan sela berupa perintah penjualan barang yang mudah rusak dan memerintahkan penyimpanan uang hasil penjualan itu pada rekening yang ditunjuk.

Dalam hal seseorang mengajukan gugatan kepada Pengadilan Negeri, bukan saja ia mengharapkan agar memperoleh putusan yang menguntungkan baginya. Namun di samping itu pula bahwa putusan tersebut akhirnya dapat dilaksanakan ${ }^{3}$. Maka dari itu hukum acara perdata memungkinkan bagi orang yang kalah dalam putusan Pengadilan Negeri untuk mengajukan Banding, dan setelah itu dilanjutkan lagi dengan mengajukan permohonan Kasasi. Pada prinsipnya putusan tidak menunggu sampai ada putusan dari Mahkamah Agung, yang mengakibatkan proses dapat berjalan hingga bertahun-tahun. Apabila tidak dikenal adanya lembaga sita jaminan, bagi penggugat yang telah dimenangkan perkaranya, pada akhirnya menjadi pihak yang 'kalah', dikarenakan proses yang memakan waktu yang lama dan memakan biaya yang tidak sedikit, sedangkan tujuannya tidak tercapai/tidak menghasilkan, bahkan biaya yang telah dikeluarkan juga tidak dapat diganti ${ }^{4}$

Berdasarkan uraian tersebut di atas, terlihat pentingnya sebuah sita jaminan. Karena sita jaminan memberikan kepastian hukum bagi pihak yang memenangkan perkara. Yang dimaksud dengan kepastian hukum, yaitu fungsi sebagai jaminan apabila suatu putusan tidak dilakukan secara sukarela, maka dapat dilakukan eksekusi terhadap objek sita jaminan tersebut. Sebagaimana telah dijabarkan di atas, konsep dari sita jaminan adalah penyitaan yang dilakukan oleh

\footnotetext{
3 Retnowulan Sutantio, S.H., Hukum Acara Perdata Dalam Teori dan Praktek 97(CV. Mandar Maju, Bandung, 2005)

${ }^{4}$ Id
} 
pengadilan atas barang bergerak atau tidak bergerak, milik penggugat atau tergugat untuk menjamin adanya tuntutan hak dari pihak yang berkepentingan atau pemohon sita. Melihat dari konsep tersebut, maka dapat kita tarik kesimpulan bahwa sita jaminan hanya dapat dilakukan atas barang dengan hak milik seseorang yang hendak dimintakan sita jaminan. Maka dari itu haruslah kita pahami terlebih dahulu apa itu konsep dari hak milik.

\section{Teori kepemilikan John Locke $^{5}$}

"Allah yang telah memberikan dunia kepada seluruh bangsa manusia, juga telah memberi mereka akal sehat untuk mempergunakan hasil bumi/alam itu sebaik-baiknya demi kehidupan mereka. Bumi dan segala isinya diberikan kepada manusia untuk mendukung dan menyenangkan hidup mereka. Dan memang semua tanaman/hasil bumi yang mereka hasilkan, dan semua binatang yang memakannya (hasil bumi itu), menjadi milik bersama bangsa manusia, karena semua itu dihasilkan secara spontan oleh tangan alam, dan tidak ada orang yang pada awal mulanya mempunyai kekuasaan ekslusif melebihi semua orang lain atas hasil-hasil alam itu, dan dengan demikian semua hasil alam itu ada dalam keadaan alami mereka, tetapi semua hasil alam itu diberikan supaya dimanfaatkan oleh manusia, maka pastilah harus ada satu atau lain cara untuk mengelolanya sebelum hasil-hasil alam dapat berguna atau bermanfaat bagi orang-orang tertentu. Buah atau daging rusa yang memberi makan kepada orang indian liar yang mengembara ke mana-mana tetapi tetap merupakan pemakaian bersama, harus menjadi miliknya, dan miliknya-artinya menjadi bagian dirinya-itu sedemikian rupa sehingga orang lain tidak dapat lagi mempunyai hak atas barang itu sebelum barang itu dapat berguna baginya untuk mendukung hidupnya."

“...dan dengan demikian tidak ada alasan untuk bertengkar tentang hak, dan tidak ada keragu-raguan tentang besarnya milik yang diberikannya. Hak dan kelancaran hidup berjalan bersama-sama. Sebab seseorang mempunyai hak atas semua yang dapat dikenai kerjanya, maka tidak ada godaan baginya untuk bekerja guna memperoleh lebih banyak daripada yang dapat dipergunakannya. Oleh karenanya tidak ada kesempatan atau kemungkinan untuk bertikai mengenai hak, ataupun untuk menyerobot ke dalam hak

5 Ignatius Haryanto, Sesat Pikir Kekayaan Intelektual 40, 41 (KPG (Kepustakaan Populer Gramedia), Jakarta, 2014). 
orang lain. Berapa besar bagian yang dapat diambil seseorang untuk dirinya sendiri akan mudah dilihat; dan sia-sia, serta curanglah, jika mengambil terlalu banyak untuk dirinya sendiri, atau mengambil lebih banyak dari yang diperlukannya."

Melihat dari pemaparan teori kepemilikan dari John Locke, dapat ditarik kesimpulan unsur dari hak milik, yaitu: kerja manusia (labor); mencampurkan/menambahkan sesuatu dengan yang sudah ada (mixing metapor); ketersediaan untuk orang lain; tidak boleh mengambil yang ada lebih dari apa yang dibutuhkan; dan mempergunakan yang ada sejauh tidak menjadi rusak atau busuk.

Menurut John Locke, akan disebut dengan hak milik apabila sesuatu itu didapat berdasarkan dari kerja manusia, dan tetap melihat kepada hak-hak dari orang lain di sekitar kita, dan hak milik tersebut menjadi sesuatu yang mutlak milik orang yang telah bekerja untuk mendapatkannya, sehingga menutup hak dari orang lain untuk mengambil sesuatu dari hak milik orang tersebut.

Untuk situasi baru dan transisi ini, John Locke merujuk kepada masyarakat politik yang konstitusional (maksudnya pemerintah) untuk melindungi hak milik seseorang6. Maka dengan demikian dalam situasi kini, kita harus melihat apa itu hak milik di dalam konsep hukum positif Indonesia, sehingga kita dapat melihat pengaruh teori kepemilikan John Locke di dalam pengertian hak milik di dalam hukum positif Indonesia.

\section{Hak Milik di dalam Hukum Positif Indonesia}

Di dalam hukum positif Indonesia diatur mengenai hak milik, sebagaimana yang tercantum di dalam pasal 570 KUHPerdata:

"Hak milik adalah hak untuk menikmati suatu barang secara lebih leluasa dan untuk berbuat terhadap barang itu secara bebas sepenuhnya, asalkan tidak bertentangan dengan undang-undang atau peraturan umum yang ditetapkan oleh kuasa yang berwenang dan asal tidak mengganggu hak-hak orang lain; kesemuanya itu tidak

6 Id. hlm. 42. 
mengurangi kemungkinan pencabutan hak demi kepentingan umum dan penggantian kerugian yang pantas, berdasarkan ketentuanketentuan perundang-undangan."

Dari ketentuan di atas, dapat kita tarik kesimpulan bahwa hak milik merupakan hak yang paling utama jika dibandingkan dengan hak-hak lainnya. Di dalam sejarahnya hak milik merupakan hak yang tidak dapat diganggu gugat (droit inviolable et sacre), tetapi dalam perkembangannya sifat tidak dapat diganggu gugatnya itu tidak lagi dapat dipertahankan, karena telah ada pembatasan. Misalnya pembatasan oleh hukum tata usaha, pembatasan oleh hukum tetangga, tidak boleh menimbulkan gangguan bagi orang lain, tidak boleh melakukan penyalahgunaan hak (misbruik van recht), dimana pelanggaran terhadap hal-hal tersebut dapat dikenai sanksi.

Dengan demikian dapat diketahui bahwa hak milik memberikan dua hak dasar kepada pemegangnya: ${ }^{7}$ pertama, hak untuk menikmati kegunaan dari suatu kebendaan; dan kedua, hak untuk berbuat bebas terhadap kebendaan itu dengan kedaulatan sepenuhnya. Dalam konteks ini berarti pemegang hak milik bebas untuk menjual, menghibahkan, menyerahkan benda yang dimilikinya kepada siapapun juga, selama hal tersebut tidak bertentangan dengan ketentuan yang memaksa dan atau melanggar kepentingan umum, atau hak-hak orang lain. Termasuk pula di dalamnya untuk membebankan, meletakkan hak kebendaan lainnya, menjaminkan, atau mengagunkan benda tersebut sebagai jaminan utang.

Sehingga berdasarkan teori kepemilikan John Locke dan definisi dari hak milik di dalam pasal 570 KUHPerdata, dapat ditarik suatu kesimpulan mengenai definisi hak milik adalah:

"Suatu hak yang didapat berdasarkan dari kerja orang tersebut, sehingga melahirkan hak bagi seseorang tersebut untuk bebas melakukan segala sesuatu terhadap apa yang diperolehnya tersebut, namun tetap memperhatikan hak-hak dari orang lain di sekitarnya."

7 Djaja S. Meliala, S.H., M.H., Perkembangan Hukum Perdata Tentang Benda Dan Hukum Perikatan 29 (Nuansa Aulia, Bandung 2007). 


\section{Sita Jaminan di dalam Hukum Positif Indonesia}

Penyitaan atau beslag memiliki pengertian sebagai tindakan menempatkan harta kekayaan tergugat berupa barang yang disengketakan, atau barang yang akan dijadikan sebagai pelunasan secara paksa ke dalam penjagaan selama proses pemeriksaan berlangsung yang dilakukan secara resmi atas perintah Hakim atau pengadilan, sampai adanya putusan pengadilan yang berkekuatan hukum tetap. Dari pengertian tersebut dapat diketahui hakikat dari adanya tindakan penyitaan, yaitu: tindakan yang dilakukan secara paksa; penempatan harta kekayaan tergugat dalam penjagaan; dilakukan atas perintah pengadilan; dan sampai adanya putusan tetap.

Hukum acara perdata mengatur secara formal mengenai adanya tindakan penyitaan yaitu sebagaimana diatur dalam pasal 227 HIR jo pasal 720 Rv tentang diperkenankannya penyitaan dalam bab yang diberi judul sebagai "Tentang beberapa hal mengadili perkara yang istimewa".

Pelaksanaan tindakan penyitaan tersebut dilakukan setelah adanya penetapan dari hakim terhadap barang yang disengketakan atau barang yang akan digunakan sebagai pelunasan hutang agar putusan yang dijatuhkan tidak illusoir atau kosong. Secara materiil perihal penyitaan juga diatur dalam pasal 1131 KUHPerdata, yaitu:

"Segala barang bergerak dan tak bergerak milik debitur, baik yang sudah ada maupun yang akan ada, menjadi jaminan untuk perikatan perorangan debitur itu."

Isi pasal tersebut dikenal sebagai asas sita jaminan umum, sehingga secara otomatis segala kebendaan milik debitur akan menjadi jaminan untuk pelunasan hutangnya, namun terbatas kepada barang bergerak dan barang tidak bergerak.

Berdasarkan pasal 227 (1) HIR 8

"Jika ada persangkaan yang beralasan, bahwa seorang yang berhutang, selagi belum dijatuhkan keputusan atasnya atau selagi putusan yang mengalahkannya belum dapat dijalankan, mencari akal

8 R. Soeroso, S.H., Hukum Acara Perdata Lengkap \& Praktis HIR, RBg, dan Yurisprudensi, 223 (Sinar Grafika 2013). 
akan menggelapkan atau membawa barangnya baik yang tidak tetap maupun yang tetap dengan maksud akan menjauhkan barang itu dari penagih hutang, maka atas surat permintaan orang yang berkepentingan Ketua Pengadilan Negeri dapat memberi perintah, supaya disita barang itu untuk menjaga hak orang yang memasukkan permintaan itu, dan kepada peminta harus diberitahukan akan menghadap persidangan, pengadilan negeri yang pertama sesudah itu untuk memajukan dan menguatkan gugatannya"

Sita jaminan mengandung arti untuk menjamin pelaksanaan suatu putusan di kemudian hari atas barang-barang milik tergugat baik yang bergerak maupun yang tidak bergerak selama proses perkara berlangsung terlebih dahulu disita, atau dengan lain perkataan bahwa terhadap barang-barang yang sudah disita tidak dapat dialihkan, diperjualbelikan atau dipindahtangankan kepada orang lain. Ini adalah menyangkut sita conservatoir (conservatoir beslag). Selain itu bukan hanya barang-barang tergugat saja yang dapat disita, demikian juga halnya terhadap barang bergerak milik penggugat sendiri yang ada dalam kekuasaan tergugat dapat pula diletakkan sita jaminan. Sita ini dinamakan sita revindicatoir ${ }^{9}$.

Sebagaimana telah diuraikan di atas, sita jaminan merupakan salah satu lembaga dari hukum acara perdata untuk mencapai tujuan dari hukum itu sendiri, yaitu mencapai adanya kepastian hukum bagi para pihak yang bersengketa. Dengan adanya lembaga sita jaminan, akan menjamin pihak yang memenangkan perkara, sehingga pihak tersebut tidak perlu merasa cemas mengenai tidak dilaksanakan suatu putusan tersebut secara sukarela.

Terdapat beberapa prinsip pokok sita secara umum yang harus ditaati. Secara khusus sita memiliki beberapa perbedaan bergantung pada jenis sita yang diajukan. Namun, berdasarkan bentuknya undang-undang mengenal beberapa jenis sita, yaitu: sita revindikasi (revindicatoir beslag); sita jaminan (conservatoir beslag); dan sita eksekusi (executorial beslag).

9 David Adrian, Perlindungan Hukum Terhadap Kreditur Atas Objek Hak Tanggungan Dari Upaya Sita Jaminan Oleh Pihak Ketiga, Lex Privatum, Vol.II/No. 1/Jan-Mar/2014. 144, 152 (2014) 
Prinsip-prinsip pokok penyitaan adalah: ${ }^{10}$

1) Sita Berdasarkan Permohonan. Pasal 226 ayat (1) HIR menyatakan bahwa proses beracara dalam permohonan pengajuan sita boleh dilakukan secara tertulis maupun secara lisan. Apabila permohonan penyitaan itu dilakukan secara lisan, maka permintaan itu dicatat dalam berita acara sidang, dan berdasarkan permintaan itulah hakim mengeluarkan perintah sita apabila pemohon dinilai memiliki alasan hukum yang kuat. Permohonan sita dapat dilakukan secara tertulis (Pasal 227 HIR). Pengajuan sita dengan format tertulis dilakukan dengan bentuk surat permintaan yang dapat dilakukan melalui disatukan dengan surat gugatan maupun secara terpisah dengan surat gugatan, yaitu dengan diajukan dalam surat tersendiri secara terpisah dari pokok perkara. Pada dasarnya permohonan sita merupakan acara voluntair, yaitu hakim tidak diperkenankan mengeluarkan penetapan sita tanpa permohonan dari penggugat.

1) Permohonan Sita Berdasarkan Persangkaan. Alasan Penyitaan merupakan tindakan perampasan harta kekayaan dari kekuasaan tergugat sebelum adanya putusan yang berkekuatan hukum tetap, sehingga harus benar-benar dilakukan secara cermat dan berdasarkan alasan yang kuat. Pasal 227 HIR mengatur mengenai alasan-alasan yang harus dipenuhi sebelum sita dilakukan, yaitu adanya sangkaan bahwa tergugat akan mengasingkan hartanya selama proses pemeriksaan perkara berlangsung yang harus ditunjukkan dengan adanya fakta dan bukti obyektif bahwa tergugat akan mengalihkan hartanya. Alasan-alasan yang telah diutarakan oleh penggugat akan dinilai oleh hakim sebagai pihak yang memiliki kewenangan untuk menerima maupun menolak alasan sita dengan didasarkan atas bukti-bukti yang obyektif.

2) Penggugat wajib menunjukkan barang obyek sita. Pasal 1131 KUHPerdata menegaskan bahwa segala harta kekayaan si berhutang menjadi jaminan

10 Sujayadi dan Yuniarti, Pelaksanaan Sita Jaminan Dalam Hukum Acara Arbitrase, Yuridika: Volume 25 No 1, Januari-April 2010, 75, 82-84, 2010. 
bagi pelunasan hutangnya. Namun hal ini tidak berarti bahwa semua harta tergugat merupakan obyek sitaan. Pada proses pengajuan sita, penggugat harus menyebutkan secara definitif mengenai barang yang menjadi akan menjadi obyek sita.

3) Permintaan dapat diajukan sepanjang pemeriksaan sidang. Pasal 127 HIR mengatur mengenai permohonan sita yang hanya dapat dilakukan selama putusan yang berkekuatan hukum tetap belum dijatuhkan. Hal ini berarti bahwa permohonan sita dapat diajukan di tengah proses pemeriksaan perkara di Pengadilan berlangsung, sehingga tidak harus selalu diajukan di awal persidangan.

4) Pengabulan sita berdasarkan pertimbangan obyektif. Prinsip ini berkaitan dengan prinsip alasan pengajuan sita harus berdasarkan alasan yang cukup dan obyektif, sehingga alasan pengabulan sita harus berdasarkan pertimbangan yang obyektif. Penggugat harus memberikan alasan bahwa obyek sita terkait erat dengan pokok perkara, yaitu untuk melindungi kepentingan penggugat pada saat putusan ditetapkan oleh pengadilan.

5) Larangan penyitaan milik pihak ketiga. Penyitaan hanya dibatasi pada barang milik tergugat, tidak diperkenankan adanya penyitaan terhadap barang milik pihak ketiga, karena akan merugikan pihak ketiga.

6) Penyitaan berdasarkan nilai obyektif dan proporsional berdasarkan jumlah tuntutan. Penyitaan yang dilakukan atas barang tergugat untuk melindungi kepentingan penggugat agar eksekusi putusan dapat dilaksanakan tidak boleh melebihi nilai dari sengketa. Sehingga sebelum dilakukan penyitaan harus dilakukan taksiran atas barang yang dimohonkan sita, penetapan penyitaan adalah berdasarkan nilai obyektif dan proporsional berdasarkan jumlah tuntutan.

7) Mendahulukan penyitaan benda bergerak. Permohonan sita yang diajukan oleh tergugat harus didahulukan pada barang-barang bergerak milik tergugat, apabila nilai barang bergerak tidak mencukupi nilai obyek sengketa, maka permohonan sita dapat diajukan atas benda tidak bergerak. 
8) Dilarang menyita barang tertentu. Semua barang milik kreditur atau orang yang berhutang dalam hal ini adalah tergugat menjadi jaminan bagi pelunasan hutangnya, tetapi ada benda tertentu yang tidak dapat dikenai sita. Pasal 197 HIR mengatur lebih lanjut mengenai barang-barang ini, diantaranya adalah bahwa benda yang menjadi modal dalam melakukan pekerjaan seseorang tidak dapat dikenai sita.

9) Penjagaan sita tidak boleh diberikan kepada penggugat. Barang yang dikenai sita berada dalam kekuasaan Pengadilan Negeri yang pelaksanaan sitanya dilakukan oleh seorang juru sita. Penempatan kekuasaan atas barang tergugat dalam kekuasaan pengadilan merupakan salah satu cara untuk menghindarkan kemungkinan barang atau obyek sengketa akan dialihkan kepada pihak ketiga.

10) Kekuatan mengikat sita sejak diumumkan. Pengumuman sita kepada pihak ketiga merupakan syarat formil untuk mendukung keabsahan dan kekuatan sita terhadap pihak ketiga. Pada sita yang telah dilakukan pendaftaran dan pengumuman maka berlaku asas publisitas, yaitu apabila pengumuman mengenai sita telah dilakukan maka pihak ketiga dianggap telah mengetahui bahwa barang yang disita berada dalam kekuasaan Pengadilan, sehingga segala macam tindakan pengalihan barang kepada pihak ketiga menjadi batal demi hukum, hal ini sesuai dengan pengaturan dalam pasal 198 HIR dan 199 HIR.

11) Sita penyesuaian. Terhadap barang milik tergugat hanya dapat diterapkan sita penyesuaian apabila pada barang yang bersangkutan sebelumnya telah dikenakan sita jaminan atau sita eksekusi atau sita revindikatoir sebelumnya. Hal ini adalah untuk melindungi kepentingan pemegang sita yang pertama, sehingga urutan yang digunakan adalah berdasarkan tanggal pertama pengenaan sita yang dapat dilihat dari masa pendaftaran dan pengumuman. Terhadap barang yang telah diletakkan agunan juga diberlakukan hal yang serupa. Barang yang telah diletakkan hak tanggungan, fidusia maupun gadai tidak boleh diletakkan sita jaminan, namun dapat diletakkan sita 
penyesuaian. Hal ini dilakukan untuk kepastian hukum pemegang agunan sebagai kreditur preferen, dengan diletakkan sita penyesuaian maka pemegang hak jaminan tetap didahulukan dari pemegang sita penyesuaian.

Apabila ditinjau dari konsep sita jaminan, inti dari sita jaminan adalah penyitaan oleh pengadilan terhadap hak milik atas benda yang memiliki nilai ekonomis dari seseorang yang dimohonkan untuk diletakan sita jaminan. Perlu diingat bahwa tujuan dari diletakkan sita jaminan adalah merupakan jaminan. Apabila pihak yang dikalahkan tidak dapat membayar ganti rugi, maka terhadap sesuatu yang diletakkan sita jaminan tersebut merupakan jaminan bagi pihak yang menang untuk dapat menutup ganti rugi tersebut melalui eksekusi terhadap sita jaminan tersebut ${ }^{11}$.

\section{Konsep Hak Kekayaan Intelektual}

Menurut Catherine Colston, definisi hak kekayaan intelektual adalah:12

"Hak kekayaan intelektual adalah segala yang berkaitan dengan hasil kreatifitas manusia. Subjek masalah ini dibentuk dari ide baru yang ditemukan oleh manusia. Ide baru bisa diaplikasikan dalam berbagai bentuk sejauh pikiran manusia dapat menghasilkannya. Aplikasinya pada kebutuhan manusia dan keinginan manusia, bisa menjadi sesuatu yang berguna bagi perkembangan kemanusiaan. Ide-ide baru tersebut bisa terwujud dalam benda-benda seperti buku, musik, seni, atau dalam bentuk mesin teknis, atau mesin proses, bisa juga berbentuk objek yang dipergunakan dalam rumah tangga ataupun dalam kepentingan industri komersil, atau dalam bentuk sumber informasi lainnya, daftar ini tidak terbatas, sebagaimana potensi yang dapat ditemukan sebagai wadah ekspresi baru. Sekali penemuan tersebut diaplikasikan pada kebutuhan manusia, nilai ide berkembang luas mulai dari, yang bersifat komersil dan industrial hingga pada dunia sastra, seni, dan desain, yang menyumbang pada perkembangan teknologi, ekonomi, sosial, dan kebudayaan."

11 Bandingkan, Sudjana, Hak Cipta sebagai Jaminan Kebendaan Bergerak dikaitkan dengan Pengembangan Obyek Fidusia, Jurnal Mimbar Hukum UGM, Volume 24, Nomor 3, 406-407, 2012.

12 Ignatius Haryanto, supra catatan pada no. 4, pada 75. 
Sedangkan menurut Colston yang dimaksud dengan hukum hak kekayaan intelektual adalah:

"hukum yang melindungi perkembangan dan aplikasi ide-ide baru yang membantu mewujudkan keuntungan yang dihasilkan darinya. Hukum kekayaan intelektual adalah alat yang dipergunakan untuk memberikan perlindungan ini. Hukum ini terdiri dari sejumlah hak yang bisa diaplikasikan dalam banyak dan beragam bentuk dimana intelegensi manusia bisa mengekpresikannya. Gambaran paling umum yang terletak di belakang hak kekayaan intelektual adalah bahwa pemilik hak bisa menghentikan orang lain mengambil hasil karya mereka. Hal ini akan melindungi integritas, dan juga melindungi ekploitasi dan mewakili hasil kreasi pemilik hak tersebut."

Konsep hak kekayaan intelektual yang dirumuskan hendak mencapai sejumlah keutamaan di bawah ini:

1) Pembuat karya dan karya yang dihasilkan harus diakui dan dihargai.

2) Atas hasil karyanya, si pembuat karya disamping memiliki hak moral (pengakuan atas dirinya sebagai peng-karya) juga memiliki hak ekonomi atas hasil karya tersebut.

3) Si pembuat karya diberikan perlindungan hukum dalam suatu periode tertentu untuk bisa menikmati hak ekonomi atas hasil karyanya (hak monopoli kreator).

4) Suatu karya yang telah melewati periode waktu tertentu memberikan kesempatan kepada masyarakat umum untuk bisa menikmatinya dengan akses yang lebih terbuka (tidak perlu membayar untuk bisa menikmati hasil karya tersebut).

5) Sejarah hak kekayaan intelektual menunjukkan adanya kecenderungan perlindungan hak monopoli si pencipta semakin panjang.

Keutamaan-keutamaan di atas hendak menunjukkan bahwa hak kekayaan intelektual memberikan perlindungan kepada seseorang yang berkarya dan hasil karyanya, dan asumsi yang melandasi pemikiran ini juga adalah konsep tentang "dengan adanya kompensasi atas perlindungan karya tersebut, maka si pecipta akan bisa menghasilkan ciptaan lain." 


\section{Konsep Hak Milik Yang Ada Di Dalam Hak Kekayaan Intelektual}

Sistem hak kekayaan intelektual merupakan hak privat (private rights). Disinilah ciri khas hak kekayaan intelektual. Seseorang bebas untuk mengajukan permohonan atau mendaftar karya intelektual atau tidak. Hak eksklusif yang diberikan negara kepada individu pelaku hak kekayaan intelektual (inventor, pencipta, pendesain, dan sebagainya) tidak lain dimaksud sebagai penghargaan atas hasil karya (kreativitas) nya ${ }^{13}$.

Sebagaimana yang telah dijabarkan di atas, konsep hak kekayaan intelektual merupakan hak privat yang berupa hak moral dan hak ekonomi, dan kedua itu dapat dikategorikan menjadi suatu hak eksklusif atas suatu karya kekayaan intelektual. Apabila diuraikan, maka hak milik dalam hak kekayaan intelektual timbul karena: pertama, pembuat karya bekerja keras untuk menghasilkan suatu karya; dan kedua, karya tersebut menimbulkan hak bagi si pencipta untuk menikmati hasil dari karyanya (hak moral, dan hak ekonomi) dan menimbulkan hak eksklusif atas karyanya itu.

Apabila melihat definisi hak milik sebagaimana yang telah dirumuskan di atas yaitu:

"Suatu hak yang didapat berdasarkan dari kerja orang tersebut, sehingga melahirkan hak bagi seseorang tersebut untuk bebas melakukan segala sesuatu terhadap apa yang diperolehnya tersebut, namun tetap memperhatikan hak-hak dari orang lain di sekitarnya."

Maka unsur hak milik dari hak kekayaan intelektual: pertama, hak kekayaan intelektual itu diperoleh dari hasil kerja keras si pembuat karya; kedua, karenanya menimbulkan hak bagi si pembuat karya (hak moral dan hak ekonomi); ketiga, pembuat karya dapat secara bebas berbuat segala sesuatu atas karyanya; dan keempat, adanya batas waktu atas hak kekayaan intelektual, yang membuat orang lain di sekitar, dapat mengakses dan menikmati hasil karya si pembuat karya (hak daripada orang lain pun diperhatikan) ${ }^{14}$.

13 DJHKI, sistem HKI, http://119.252.161.174/sistem-hki/ (terakhir diakses 20 Agustus 2015).

14 Contoh: dalam paten, setelah jangka waktu perlindungan, teknologi tersebut menjadi public domain, sehingga dapat berguna bagi masyarakat sekitar. 
Sehingga yang dimaksud dengan hak milik dari hak kekayaan intelektual adalah hak eksklusif atas karya intelektual tersebut. Karena dengan diberikannya hak eksklusif atas karya intelektual tersebut, pemegang hak eksklusif tersebut dapat dengan bebas menggunakan hak eksklusif tersebut dalam arti pihaknya dapat menggunakan, memperbanyak, dan mengalihkan (menjual ataupun memberikan lisensi), dengan tetap memperhatikan hak orang lain di sekitarnya (adanya pembatasan terhadap hak eksklusif dari hak kekayaan intelektual).

\section{Peletakan Sita Jaminan Pada Objek Hak Kekayaan Intelektual}

Apabila melihat inti dari sita jaminan, sita jaminan bertujuan untuk menjamin pihak yang dikalahkan membayar ganti rugi kepada pihak yang memenangkan perkara, sehingga dalam sita jaminan ada 3 kriteria utama sebagai obyek untuk diajukan sita jaminan, yaitu:

1) Hak milik atas benda milik Tergugat;

Kita tidak boleh meletakan sita jaminan terhadap hak milik orang lain yang tidak berkepentingan selain tergugat.

2) Mempunyai nilai ekonomi;

Selayaknya jaminan utang, sita jaminan ditujukan untuk merupakan jaminan bagi pihak yang memenangkan perkara, agar pihak yang dikalahkan memenuhi kewajibannya, maka dari itu sudah seharusnya, suatu jaminan haruslah mempunyai nilai ekonomi.

3) Dapat dialihkan.

Apabila pada akhirnya pihak yang dikalahkan tidak menjalankan kewajibannya secara sukarela, maka dapat dilakukan eksekusi terhadap sita jaminan tersebut, maka sudah seharusnya sita jaminan merupakan benda yang dapat dialihkan,

Hak kekayaan intelektual di dalamnya terdapat hak moral dan hak ekonomi yang menjadi hak milik daripada si pemegang hak kekayaan intelektual. Yang dapat dialihkan di dalam hak kekayaan intelektual adalah hak ekonomi atas hak kekayaan intelektual tersebut (melalui lisensi, jual beli, ataupun pewarisan). 
Hak moral atas kekayaan intelektual terus melekat terhadap orang yang menghasilkannya, sehingga tidak dapat dialihkan.

Menurut Penulis, apabila sesuatu benda hendak diajukan sita jaminan, maka benda tersebut haruslah memenuhi ketiga syarat utama dari sita jaminan tersebut. Apabila ketiga syarat tersebut terpenuhi maka terhadap benda yang memenuhi ketiga syarat tersebut, dapat diletakkan sita jaminan.

\section{Penutup}

Hak kekayaan intelektual memenuhi syarat untuk dapat diletakan sita jaminan, sehingga dapat disimpulkan dapat diletakan sita jaminan atas hak kekayaan intelektual, namun terbentur akan adanya pasal 1131 KUHPerdata, dimana sita jaminan hanya terbatas kepada benda bergerak dan benda tidak bergerak. Namun apabila melihat inti dan tujuan dari sita jaminan, menurut Penulis, peletakan sita jaminan dapat dilakukan terhadap obyek kekayaan intelektual, namun hanya terbatas pada hak ekonomi atas hak kekayaan intelektual, tidak termasuk hak moral atas hak kekayaan intelektual di dalamnya. Sehingga saran yang dapat diajukan oleh penulis adalah adanya perubahan terhadap pasal 1131 KUHPerdata, dikarenakan sudah tidak sesuai lagi dengan perkembangan hukum di Indonesia pada masa ini.

\section{Daftar Pustaka}

\section{Buku:}

Djaja S. Meliala, Perkembangan Hukum Perdata Tentang Benda Dan Hukum Perikatan. Nuansa Aulia, Bandung 2007

Ignatius Haryanto. Sesat Pikir Kekayaan Intelektual. KPG (Kepustakaan Populer Gramedia), Jakarta, 2014

M. Yahya Harahap. Ruang Lingkup Permasalahan Eksekusi Bidang Perdata. Sinar Grafika, Jakarta, 2006

Retnowulan Sutantio, Hukum Acara Perdata Dalam Teori dan Praktek. CV. Mandar Maju, Bandung, 2005

R. Soeroso, Hukum Acara Perdata Lengkap \& Praktis HIR, RBg, dan Yurisprudensi. Sinar Grafika 2013 
Sudikno Mertokusumo. Hukum Acara Perdata Indonesia. Liberty, Yogyakarta, 1998

Jurnal:

David Adrian. Perlindungan Hukum Terhadap Kreditur Atas Objek Hak Tanggungan Dari Upaya Sita Jaminan Oleh Pihak Ketiga, Lex Privatum, Vol.II/No. 1/Jan-Mar/2014

Sudjana. Hak Cipta sebagai Jaminan Kebendaan Bergerak dikaitkan dengan Pengembangan Obyek Fidusia, Jurnal Mimbar Hukum UGM, Volume 24, Nomor 3, Okober 2012

Sujayadi dan Yuniarti. Pelaksanaan Sita Jaminan Dalam Hukum Acara Arbitrase, Yuridika: Volume 25 No 1, Januari-April 2010

Web Document:

DJHKI, sistem HKI, http://119.252.161.174/sistem-hki/ terakhir diakses 20 Agustus 2015 